\title{
A Functional Analysis of Passive Clauses in Selected Independence Speeches of Nigerian Heads of Government
}

\author{
Dr. Samuel Adebayo OMOTUNDE \\ Department of English and Literary Studies \\ Ekiti State University \\ Ado-Ekiti, Ekiti State, Nigeria \\ E-mail: samueladebayo980@yahoo.com
}

Dr. Samuel Alaba AKINWOTU (Corresponding Author)

Department of English Studies

Adekunle Ajasin University

P.M.B. 001, Akungba-Akoko, Nigeria

Tel: 234-0803-3612-528Ｅ-mail: samuelakinwotu@gmail.com

Received: August 3, 2018 Accepted: September 7, 2018 Published: September 10, 2018

doi:10.5296/jsel.v6i1.13629 URL: https://doi.org/10.5296/jsel.v6i1.13629

\begin{abstract}
Scholarly works on political discourse have been from different perspectives but there is a dearth of work on the functional analysis of passive clauses in political speeches. Even though fragments of the general functions of the passive clause can be gleaned in some grammar books, its deployment in connected discourse has not been adequately explored. This is a gap which the current paper fills. The paper which adopts Systemic Functional Grammar (SFG), examined six purposively selected Independence Anniversary speeches of Nigerian Heads of Government from 1967 to 2016, sourced from the internet and the national dailies like "The Punch", "The Guardian" and "The Tribune". The paper has revealed that there are different kinds of passive clause but the short be passive is most the commonly used. Passive clauses perform six main functions in connected discourse and they are used for the purpose of foregrounding information or achieving information focus.
\end{abstract}

Keywords: Passive clauses, Systemic Functional Grammar, Independence Anniversary Speech, Nigerian Heads of Government 


\section{Introduction}

The significance of language in all political texts and talks makes it an attractive scholarly venture. Language and politics are intertwined to such an extent that we cannot conceive of politics without language. It is the means through which politicians pass across different ideas, messages, information, policies or ideologies to their followers through formal speeches or talks. Affirming this, Ranney (1975:130) writes that "every political authority will need to justify itself by an appeal to language in its symbolic or realistic sense. Ayeomoni $(2005: 155)$ also declares that "it is widely conceived that language and politics are interconnected. Language, for instance, is considered the vehicular expression of politics. It is the means by which politics or political discourse and ideas are widely disseminated". Omotunde (2014:31) corroborates the above quotations by writing that "every political leader under any form of political system-civilian or military relies on the medium of language to govern people, convey his ideas, philosophy and ideologies, and channel his policies to his followers for the purpose of achieving his aims of being in power". All the above views reveal that political affairs and issues can only be successfully carried out through the instrumentality of language. No wonder, Akinkurolere (2011:2) writes that "politicians are usually supported by citizens based on what they say and how they say it whether in candidacy, programmes, or policies". Language is important in the construction and interpretation of political discourse. By political discourse, we mean discourse "about the text and talk of professional politicians or political institutions, such as Presidents and Prime Ministers and other members of government, parliament or political parties, both on the national and international levels" (van Dijk, 1997:12). He further adds that the text must have political functions and implicatures (pg. 18) (emphasis not ours).

However, in the process of encoding their speeches, politicians and office holders may manipulate the intended meaning of an utterance or a sentence (the full import of which may not be known by casual listeners or readers) by tampering with the natural order of sentence elements through focusing, omission, movement, addition etc. This is why Thorne (2008:419) writes that "politicians can influence the way we think about the events happening around us, and the words they choose are a crucial part of that process". Writing to support why politicians or political leaders' speeches should be taken with caution, Nahrkhalaji (n.d:3) declares that "we should never... read/hear others' words without being conscious of the underlying meaning of the words. The words of those in power are taken as self-evident truths and the words of those not in power are dismissed as irrelevant, inappropriate or without substance". The above quotations reiterate the fact that readers/listeners should pay adequate attention to political speeches or discourse in terms of meaning. In fact, it is in the realization of the significance of knowing the different shades of meaning in politicians' or political leaders' speeches that linguistic scholars have deployed various linguistic tools and theories towards interpreting political speeches/discourse.

Linguistic investigations of political speeches especially presidential political speeches in different climes have been carried out using different linguistic approaches. Few of these are reviewed below: Ayoola (2005) uses CDA to interpret former President Obasanjo's July 26, 2005 address to Nigeria's National Assembly. The work attempts to make explicit the 
linguistic choices President Obasanjo makes and the reasons for making such choices. Pu's (2007) work centres on linguistic and rhetorical devices in the speech of Bush which he delivered at Tsinghua University. Adetunji (2009) adopts Speech Act Theory and Rhetoric as theoretical orientations in the analysis of the Inaugural Address of Nigeria's President Olusegun Obasanjo and President George, W. Bush of America. The work of Okpanachi (2009) entitled "Discourse Analysis of President Obasanjo's National Address on the Nigerian Labour Congress (NLC) on 8th October, 2003" is also germane to this review. The work analyses "how the president has used the resource of the language to categorise and portray himself and the NLC". The paper shows how Obasanjo through the resources of language portrays the NLC as an unpatriotic body who does not have the interest of the ration at heart while portraying himself and his administration as working for the interest of the nation and Nigerians as a whole. Akinwotu (2015a) examines the pragmatic strategies in media political competitive encounters. The paper which adopts a combination of Brown and Levinson (1987) politeness and facework, Watts' (2003, 2005) relational work and frame theory to analyse the final session of the Ondo State governorship election media debate of 2012 reveals that "two types of verbal behaviour (polite and impolite), projected by three context-driven politeness strategies (persuasive, offensive and defensive), marked contestants' utterances". Akinwotu, S.A. (2015b) accounts for the pragmatic functions of language use in elections crises in Nigeria. The paper which accounts for the context-driven roles of language in the selected speeches reveals five pragmatic acts of threat namely warning, accusing, condemning, rejecting and criticising driven by five issues (leadership crisis, economic crisis, military dictatorship, electoral malpractice and annulment). Also relevant is Akinwotu (2016) which investigates rhetoric in selected speeches of Obafemi Awolowo and Moshood Abiola. The study reveals that two types of rhetoric, combat and tact, are significant in selected speeches.

Wang's (2010) paper titled, “A Critical Discourse Analysis of Barack Obama's Speeches”, adopts Systemic Functional Grammar to analyse selected speeches of President Obama mainly from the angle of transitivity and modality. Abuya (2012) uses the theoretical framework of pragma-stylistics to analyse President Goodluck Ebele Jonathan's Inaugural Speech of May 2011. In the same vein, Aschale (2013) uses critical discourse analysis to investigate Barack Obama's speeches vis-à-vis Middle East and North Africa. He accounts for Obama's use of language to establish morality and religion; change; ideology and contestations; and identity and background in the selected speeches. Also, Jabber and Jinquan (2013) adopt Speech Act Theory to investigate how modal verbs are used in making requests in selected speeches of President Obama. Jarraya's (2013) work centres on persuasion in political discourse with Ben Ali's last speech as a case study. He makes use of insights from Speech Act Theory, Aristotle's persuasive strategies and the Cooperative Principle of H.P Grice.

As significant and relevant the above works may be, none of them has characterised the types and the possible functions or reasons for adopting passive clauses in selected Independence Anniversary Speeches of Nigerian Heads of Government. This paper fills this gap. 


\section{Theoretical Framework}

The grammatical theory adopted for this work is M.A.K Halliday's Systemic Functional Grammar (henceforth, SFG). The theory is based on the functions of language rather than on the rules governing the nature of language. This shows that the grammar is not rule centred. SFG is basically concerned with meaning. Bloor and Bloor (1995:1) captures the above by writing that the grammar is "the study of how meanings are built through the use of words and other linguistic forms such as tone and emphasis. Halliday (1994:15) writes that "language is a network of systems or interrelated sets of options for making meaning, thus, language is "systemic". Martin and Mathienssen (1997:3) write that the language makes it possible to have more knowledge about language in context and that it provides us with "a tool for understanding only a text the way it is".

The grammar identifies three metafunctions of language which are ideational, interpersonal and textual. One unique thing about SFG is the notion of "choice" which is built into it. It sees language as being made up of different systems from which a language user at a point in time selects. Bloor and Bloor (1995:2) write that:

Halliday's explanation of how language works involves the idea that a language consists of a set of systems each of which offers the speaker (or writer) a choice of ways of expressing meanings... Linguistic choice is not only available to speakers with regard to interrogatives, imperatives and declaratives, it operates at every point of production in speech, linguistic choice permits us to change the order of groups of words.

Bloor and Bloor (1995:3) conclude that "speakers or writers choose the forms that best express the meanings that they wish to convey and that do not express superfluous meanings". This is very essential in that Fontaine (2013:11) writes that "there is general agreement that meaning is choice and choice is meaning". We have decided to adopt SFG for this research for two reasons. First, we believe that the use of passive sentences in the texts under analysis is a deliberate choice by the encoders. Second, we have chosen SFG because of the importance it attaches to linguistic forms viz-a-vis the functions they perform in their context of occurrence. In other words, the passive sentences identified in our data perform some functions which this paper investigates.

\section{Data for the Study}

The data for this study are selected Independence Anniversary Speeches of Nigerian Heads of Government. According to Omotunde (2014) they are speeches delivered on every October 1 to mark the country's attainment of political independence from Britain. The speeches were recovered from the internet and from major Nigerian newspapers recovered from the nation's 
archives especially that of October 1, 1967 and Oct. 1, 1975. We have chosen these speeches because they provide avenues through which Nigerian Heads of Government address various issues, hence, a reliable opportunity through which a researcher can variously investigate the language that is used. The speeches are purposively selected and they cover three speeches delivered by Military Heads of Government and another three rendered by their civilian counterparts. The details are shown below:

Table 1.

\begin{tabular}{|l|l|l|l|}
\hline Text & \multicolumn{1}{|c|}{ Date } & \multicolumn{1}{|c|}{ Encoder } & $\begin{array}{c}\text { Administrative } \\
\text { Background }\end{array}$ \\
\hline I & Oct. 1, 1967 & General Yakubu Gowon & Military \\
\hline II & Oct. 1, 1975 & Brigadier Muritala Muhammed & Military \\
\hline III & Oct. 1, 1985 & General Ibrahim Babangida & Military \\
\hline IV & Oct. 1, 1999 & President Olusegun Obasanjo & Civilian \\
\hline V & Oct. 1, 2010 & President Goodluck Jonathan & Civilian \\
\hline VI & Oct. 1, 2016 & President Muhammadu Buhari & Civilian \\
\hline
\end{tabular}

The paper investigates the frequency of the passive clauses in the speeches chosen and the types they belong to using Pullum (2014) criteria. It also accounts for the possible functions they perform in the context of their occurrence.

\section{The Concept of Passive Voice in English}

Two types of voice which occur in the English language are active and passive voice. "Voice", according to Probst, et al (1997:1225):

Is the form a verb takes to indicate whether the subject of the verb performs or receives the action. A verb is in the active voice when its subject performs the action. A verb is in the passive voice when its subject receives the action. A passive voice verb is always a verb phrase that includes a form of be and the past participle of an action verb.

Kirkpatrick (2007:149) writes that "in the case of sentences using the active voice of the verb, 
the subject performs the action described by the verb. In the case of sentences using the passive voice of the verb", the subject is the recipient of the action of the verbs. The author gives the following as examples of sentences in the active voice and passive voice.

1a. The boy threw the ball (Active)

b. She is driving the car too fast (Active)

(pg. 148)

2a. The ball was thrown by the boy (Passive)

b. The car was being driven too fast by her (Passive)

(pg. 149)

Perhaps, the most current work on English passive is that of Pullum (2014) who explains the nature of English passives and equally gives its various types. He submits further that "it is not verbs that exhibit passive voice in English, but larger units... passive clauses are marked by the use of devices (participial inflections and accompanying verbs) that have other uses too". Pullum (2014) condemns the expression used for passive as a construction where "the subject receives the action expressed by the verb". He then cites the following examples:
a. Not much is known by biologists about the coelacanth.
b. It was alleged by the committee that the Dean was incompetent
c. That capitalism works is no longer doubted by anyone.

Thus, Pullum remarks that "in none of these does the subject denote anything that could conceivably be said to "receive" or be targeted by an action. This is a fundamental assertion made by Pullum which, perhaps, no other scholar has made. He identifies two basic types of passives which are:

1. Passives with be which he divides into long passive and short passive; and

2. Other kinds of passive clause which he classifies into:
i. Prepositional passives
ii. Bare passive clauses
iii. Embedded passives
iv. Get passives 
v. Concealed passives, and

vi. Adjectival passives.

\section{Passives with $b e$}

This is "the most familiar and neutral kind of passive clause" (Pullum, 2014:3). In this type, the main clause verb is in the be form with "a past-participial VP complement (Pullum, 2014:3). Pullum distinguishes between long and short passives. Thus, he refers to a passive clause with a by-phrase, as a long passive and the one without a by-phrase as a short passive. He gives the following examples to illustrate the point:

a. The president's authority has been much diminished by recent events in Washington (long passive)

b. The president's authority has been much diminished (short passive)

Pullum writes that "a short passive does not have an exact active counterpart". This paper makes use of the above distinction in its analysis.

\section{Other types of Passive Clause}

I. Prepositional Passives: This exemplifies a situation where a prepositional phrase serves as the complement of the verb in a passive clause. Pullum writes that prepositional passives may be long or short. The following are his examples:

a. He was laughed at by his friends.

b. He was laughed at.

II. Bare Passive Clause: This is a passive clause that contains only a subject and the past participle of a verb. In other words, bare passives have no "tensed verb" and "they cannot generally occur as full sentences" (Pullum, 2014:4). He gives the following sentences with the underlined as examples of bare passives.

a. That said, however, Korea is Korea, not the Philippines.

b. One of its ads shows a crashed-out manager, arms folded, sitting in a corner.

III. Embedded Passives: These are passives that are "embedded in active clauses". In this situation, "various transitive verbs with causative, inchoative, or perception meanings take subjectless bare passive complements" (Pullum, 2014:5) He cites the following examples: 
a. The government had the case investigated by the police (Embedded passive)

b. I had the suit made by my tailor in Rome

iv. Get Passive: This is a case where the verb "get" although not an auxiliary verb is used in forming passive clauses: Thus, Pullum gives the following examples:

a. A journalist photographed Marie (Active)

b. Marie was photographed by a journalist

c. Marie got photographed by a journalist

Thus, "c" above illustrates the "get passives" form.

v. Concealed Passive: These passives, according to the scholar, adopt "a gerund-participle rather than a past participle as head. The following are examples cited by the scholar:

a. This rug badly needs washing

b. The situation needs looking into by experts.

However, the authors of this paper have discovered another type of passive which perhaps is not yet in the literature on passive clauses. This is the type we will call the "have" passive. This may take any of the "have" forms (has, have, had) + Noun or Pronoun + the past participle of a verb. This newly discovered passive form can equally be long or short; that is, it can take "by phrase" or not. The following are our examples:

a. I have had the book published (short passive)

b. I have had the book published by the publisher (long passive)

c. Make sure that you have the car repaired (short passive)

d. They had the agreement terminated in the court by the Federal Government (long passive).

This newly discovered passive form is exemplified once in our data.

\section{Functions of the Passives}

Different scholars have identified different functions that passive sentences perform in a text. Kirkpatrick (2009) declares that:

i. Passive clause is used when the person who carries out the action expressed by the 
verb is not known yet;

ii. Passive is equally adopted where it is not known whose opinion is being given;

iii. Passive is also used in scientific or specialist writing where the exact identity of the person performing the action of the verb is not really important.

According to English Learners Stack Exchange (an Internet Source), passive construction is used because;

i. what is essential is the action itself and not really the person who performed it.

ii. the writer or speaker does not know or does not care who performed the action.

iii. what is of utmost significance is the result of the action rather than who performed it.

iv. one wants one's readers to think of the action as impersonal

v. the agent is inconsequential, unknown or something you do not want to mention.

Using insights from the above, this study shall attempt to examine the functions of the passive clauses in the texts under analysis and also justify their adoption in some cases. It is equally our aim to indicate that the functions of passive clauses transcend the ones already identified in the literature as will be revealed in our analysis.

\section{Data Presentation and Analysis}

Our analysis below is divided into two:

i. Functional Analysis of Passive Sentences in the Data

ii. Statistical Analysis of Passive Sentences in the Data

\subsection{Functional Analysis of Passive Clauses in the Data}

The following are the functions of the passive clauses in the data under analyses. In each case, the verb phrase that indicates the passive is underlined

1. Passives are used to give the impression that the agent of the action/event referred to in the passive clause is known by everybody. This is a case where the short be passives are used and the encoder believes that the listeners or readers should be able to recover the agent from the context. The following are few examples from our data. 
a. Every avenue of peace was fully explored (by the Federal Military Government), beginning with the ad hoc constitutional conference of August $1966 \ldots$ (Oct 1, 1967)

b. Committees have also been set up (by the Federal Military Government) to examine the various problems of economic and social reconstruction in the post war (Oct. 1, 1967)

c. During the first stage, the state issue will be settled and any new states created will be fully established (by the Government or Federal Military) (Oct. 1975)

d. Laws are made (by the legislature) mainly to preserve the integrity of the state but the added responsibilities I speak of here are intended (by the Government) to preserve the spiritual bases of our community (Oct. 1, 1999)

e. It is in this same spirit, also, that we have introduced, through the National Orientation Agency, the new campaign for National Rebirth. This campaign is intended (by the Federal Government) to emphasise, not only the obligation of... (Oct. 1, 1999)

f. We are blessed (by God) with talented and patriotic Nigerians at home and in the Diaspora, many of whom are willing and ready to return home... (Oct. 1, 2010)

g. On security, we have made progress. Boko-Haram was defeated (by the Nigeria Military) by December - only resorting to cowardly attacks (Oct. 1, 2016)

In all the above examples, the agents of the actions or events are provided in parenthesis. They are not supplied by the speakers because they assumed that the listeners or readers already know them. They are provided by us for clarity. Speakers employed these passive constructions (underlined) to avoid stating the obvious and perhaps, to save time. Passives in this category are usually employed to communicate shared assumption arising from common knowledge of the contexts. This is a function of the passive that has not been identified in the literature.

2. The passives in our data are used to indicate that it is the action or event expressed in the clause that matters rather than the agent or the performer. In this situation, the passives give an impersonal tone. This is the commonest function of the passives in our data. Below are few examples from the speeches under analysis.

h. The Government-sponsored Radio Enugu and all the newspapers in the East were organised to whip up the emotions of the people, rumours were spread of 
impending attacks on Lagos... (Oct. 1, 1967)

i. Unfortunately, Ojukwu's propaganda is being re-echoed in the foreign press and radio with tragic consequences for his rebel soldiers (1967).

j. It was in this charged atmosphere that the well-founded story was released about the massacre of a large number of men and women and children of Northern origin resident in the East (1967).

k. All members of staff found wanting in efficiency or probity or found unsuitable in any other way were retired with full benefits (1975)

1. The Nigerian economy has to be modernised and there must be room for personal initiative and drive. Merit will be promptly rewarded and indolence punished (1975)

$\mathrm{m}$. We are open to dialogue, but we will not succumb to intimidation, violence and criminality. All culprits will be punished (Oct. 1, 1999)

In " $h$ " above, the underlined passive is the focus of attention. In other words, the effect of the Government-sponsored Radio Enugu and the newspapers that "were organized" which succeeded in whipping up emotions is the main issue rather than the agent(s) which organized them. Also, the rumours that "were spread" together with its damaging consequences during the civil war is more significant than dwelling on those who spread the rumours. In the two cases above, it may not be easy to know those who were behind the acts. In " $i$ ", the propaganda that "is being re-echoed" with its tragic consequences on the Biafrans seemed more important than the agent. In the case of " $\mathrm{j}$ ”, the speaker merely reports the incident by employing the technique of distancing self from the information focus. The agent who released the "well founded" story may have been intentionally omitted for security reasons. The main thing is "that the well-founded story was released". In examples " $k$ " and "l", the encoder of the speech assumed the institutional voice while revealing some policies which his administration had designed in order to rid the country of inefficiency and corruption. In order to make the policies sound impersonal and make the message to be forceful, the encoder uses the short be passives. Hence, there are "were retired... in "k" and "... promptly rewarded and indolence punished" in "l".

In the case of " $\mathrm{m}$ " above, culprits may be punished in several ways and by different authorities in Nigeria. In essence, the encoder, President Olusegun Obasanjo assumed the voice of an institution, speaking on behalf of his administration by stressing the action in an impersonal form. At that point, the agent that will give the punishment does not matter. He only wants those who are concerned to be informed about the decision of government on the fate that may befall them if they do not stop their criminal acts.

3. Another function of passive clause in our data is its use as Face-Saving Act. That is, a 
polite use of language to avoid embarrassing some people. Below are few examples from our data:

n. Historically, about half of our total export earnings go to importation of petroleum and food product. Nothing was saved for the raining day during the periods of prosperity (Oct. 1, 2016)

o. Many contractors who have not been paid for three years have now mobilized to sites (2016)

The speaker, in excerpt " $n$ " above, accuses the actors whose name was not mentioned in the speech of spending without saving. He, however, deliberately concealed the identity of the actors in order not to cause disaffection. Obviously, he is referring to the presidents who ruled during the 'periods of prosperity'. Ordinarily, he should have mentioned the names of those presidents who did not save during the periods of prosperity after "was saved" in the excerpt, but he chooses not to in order not to embarrass them or incur their wrath. Hence, the adoption of the short passive be as a Face-Saving Act. The encoder had only spent a year and few months in office when the anniversary speech from which excerpt "o" was culled was delivered. Hence, he was not the head of the administration which did not pay "many contractors" for three years. Consequently, after "have not been paid" the speech encoder should have given through "by phrase" the name of the President who should have paid the contractors. However, once again, he chooses not to. This is a form of politeness introduced through passive clause. Again, this function of the passive has equally not been explored in the literature.

4. Passive clauses can also be deployed to perform some pragmatic functions. In our data, the short be passive is pragmatically used for the purpose of reducing the prominence of the agent of the event or action expressed by the passive. This function of the passive is only attested in one of the speeches used in this paper - Oct. 1, 1967. The Head of State then General Yakubu Gowon- in the speech made reference to some negative things done by the Biafrans which ordinarily would have been on the order of the rebel leader - Col. Odumegwu Ojukwu. However, in order not to make an unnecessary hero of the rebel leader or in order not to mystify him, Yakubu Gowon only used the short be passives to reveal some of these events. Few examples of these are:

p. Ibo employees in the Western states and in Lagos were stampeded into returning home... (Oct. 1, 1967).

q. ... but it is also well-known that the Post Office vans and the postal orders

which were sent to the East by the Federal Government in the implementation

of the committee's recommendations were seized in Enugu in further 
defiance

of the Federal Government.

r. Instead not only were military provocations stepped up on the innocent villages of the Benue/Plateau State... (Oct. 1, 1967).

In the speech, Ojukwu is mentioned sixteen (16) times in connection with various activities, events, and various accusations were leveled against him. Ordinarily, after each of the passives above, a "by phrase" containing "Ojukwu" or "Ojukwu and his cliques", or Ojukwu and his collaborators" should have followed. In other words, the passives should have been in the following forms below:

p. “... were stampeded by Ojukwu (and his cliques)

q. “... were seized by Ojukwu (and his rebel soldiers)

r. “... were military provocations stepped up by Ojukwu (and his disgruntled elements).

However, if this had been done, Ojukwu would have become too prominent in the speech, hence, would have been made a hero unintentionally. It is perhaps, in order not to mystify him that the short be passives are adopted. Again, the inclusion of the by-phrase would have made the accusation too bare and would have further deepened the disaffection between the two warring sides. In fact, the above function agrees with the view of Huseman et al (1988:59) that "... you may choose to use the passive voice when you want to de-emphasize the doer, or when you don't know who is responsible for the action". In the above, the speech encoder uses passive voice "to de-emphasize the doer". This function of the passive has also not been given much attention in the literature especially in the context in which it is discovered here.

5. Passive clause is also used in making what appears to be a strong commitment or intention in political speeches. In other words, politicians may employ passive clauses to make statements to which they may not be committed. To this end, the short be passives with the structure "will + be + the past participle" is used or other similar structure. The following are examples from our data.

s. Programmes of expanded production will be pursued in the context of specific commodities like rice, maize, sorghum, cassava, fish, vegetable oil and animal production (Oct. 1, 1985).

t. The development and provision of potable water is a field calling for federal initiative in both urban and rural areas. In this regard, imperative programmes will be explored for training, storing and utilizing rain water on an extensive scale 
(Oct. 1, 1985).

u. In addition, parastatals will be generally encouraged to subject themselves to the discipline of the capital market (Oct. 1, 1985).

v. In this connection, the steel industry and vehicle assembly plants must be revamped to fulfill their mission as springboard for the nation's technological development (1985).

In the excerpts above, General Babangida uses the passive clause to make promises and draw attention to what he plans to do to solve some problems facing the country. Although the intentions inherent in the utterances are given prominence rather than their agents, the possibility cannot be ruled out that politicians or political leaders can use the passive clause to avoid being committed to what they have expressed. For example, it is not stated whether it is the Federal Government or State Government or some agencies that will "pursue" the programme of expanded production mentioned above, likewise, example " $t$ ". Even, it is not clear what he means by "encouraged" in example "u". Simply put, General Babangida may have deliberately used the passives to make the utterances above to be non-committal or even vague. To clarify the above point, in example "t", while "storing" and "utilizing" collocate with rain water; training" does not, hence, the whole utterance is vague or meaningless. Excerpt " $v$ " above is also unique or worthy of attention based on its adoption of passive clause. For example, there is nothing to suggest in the excerpt or the speech that it is his administration that will revamp the steel plant industry and vehicle assembly plant. He never hints at who will revamp it and when it will be revamped. Simply put, the use of "must be revamped" is a passive construction which expresses "logical necessity" but silent on "who" will do the revamping and "which administration" will do the revamping. Our analysis and comments above agree with the view of Thorne (2008:77) that "the passive voice gives an air of authority to a text: it can suggest that the content is beyond debate and give weight to what may in fact be spurious claims".

6. The Passive clause in our data is used to indicate what a third party does on its own with the speech encoder either intentionally or unintentionally hinting that the he/she or the institution which he/she represents does not play any part or much part in it. In this case, the speaker represents the Federal Government. There is only one instance of this in our data. In fact, it is the new form of passive discovered by the authors of this paper which they referred to as the "have passive".

w. In addition, fourteen solar power projects have had their power purchase agreements concluded (Oct. 1, 2016) 
The issue of constant electricity supply has been a problem in Nigeria. Successive administrations have tried to solve the problem but all to no avail. Hence, the main aim of the speech encoder in the excerpt above is to intimate Nigerians with one of the various ongoing efforts at restoring constant electricity supply to Nigeria without giving the details of the initiators of the projects. As a matter of fact, the passive also carried the additional meaning that the "solar power projects" are not Federal Governments projects and that the encoder is merely reporting the development.

\subsection{Statistical Analysis of Passive Clauses in the Data}

The table below presents the summary of the significance of passive clauses in our data.

Table 2.

\begin{tabular}{|c|c|c|c|}
\hline Text & \multicolumn{2}{|c|}{$\begin{array}{c}\text { Frequency of Occurrence of } \\
\text { the Different Types of Passive } \\
\text { in each Text }\end{array}$} & Total \\
\hline 1 & 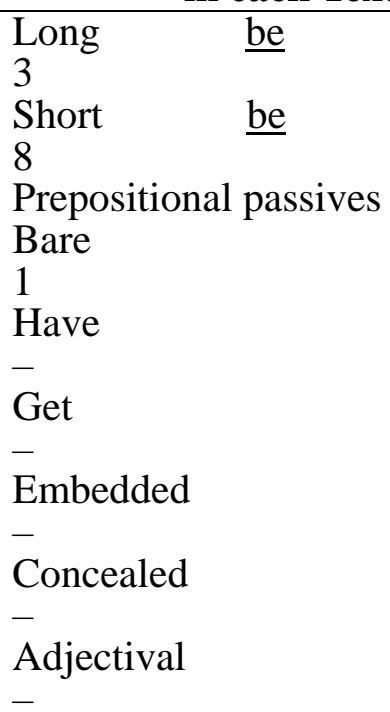 & $\begin{array}{l}\text { passives } \\
\text { passives } \\
\text { passives } \\
\text { passives } \\
\text { passives } \\
\text { passives } \\
\text { passives } \\
\text { passives }\end{array}$ & 12 \\
\hline 2 & $\begin{array}{l}\text { Long } \quad \underline{\text { be }} \\
- \\
\text { Short } \quad \text { be } \\
14 \\
\text { Prepositional passives } \\
\text { Bare } \\
- \\
\text { Have } \\
- \\
\text { Get } \\
- \\
\text { Embedded } \\
- \\
\text { Concealed } \\
- \\
\text { Adjectival } \\
-\end{array}$ & $\begin{array}{c}\text { passives } \\
\text { passives } \\
\text { passives } \\
\text { passives } \\
\text { passives } \\
\text { passives } \\
\text { passives } \\
\text { passives }\end{array}$ & 14 \\
\hline
\end{tabular}




\begin{tabular}{|c|c|c|c|}
\hline 3 & $\begin{array}{l}\text { Long } \quad \underline{\text { be }} \\
\overline{\text { Short }} \quad \text { be } \\
10 \\
\text { Prepositional passives } \\
\text { Bare } \\
- \\
\text { Have } \\
- \\
\text { Get } \\
- \\
\text { Embedded } \\
- \\
\text { Concealed } \\
- \\
\text { Adjectival } \\
-\end{array}$ & $\begin{array}{l}\text { passives } \\
\text { passives } \\
\text { passives } \\
\text { passives } \\
\text { passives } \\
\text { passives } \\
\text { passives } \\
\text { passives }\end{array}$ & 10 \\
\hline 4 & $\begin{array}{l}\text { Long } \quad \underline{\text { be }} \\
- \\
\text { Short } \quad \text { be } \\
12 \\
\text { Prepositional passives } \\
\text { Bare } \\
2 \\
\text { Have } \\
- \\
\text { Get } \\
- \\
\text { Embedded } \\
- \\
\text { Concealed } \\
- \\
\text { Adjectival } \\
-\end{array}$ & $\begin{array}{l}\text { passives } \\
\text { passives } \\
\text { passives } \\
\text { passives } \\
\text { passives } \\
\text { passives } \\
\text { passives } \\
\text { passives }\end{array}$ & 14 \\
\hline 5 & $\begin{array}{l}\text { Long } \quad \underline{\text { be }} \\
2 \\
\text { Short } \quad \text { be } \\
8 \\
\text { Prepositional passives } \\
\text { Bare } \\
- \\
\text { Have } \\
- \\
\text { Get } \\
- \\
\text { Embedded } \\
- \\
\text { Concealed } \\
- \\
\text { Adjectival } \\
-\end{array}$ & $\begin{array}{l}\text { passives } \\
\text { passives } \\
\text { passives } \\
\text { passives } \\
\text { passives } \\
\text { passives } \\
\text { passives } \\
\text { passives }\end{array}$ & 10 \\
\hline 6 & $\begin{array}{l}\text { Long } \\
-\end{array}$ & passives & \\
\hline
\end{tabular}
2018, Vol. 6, No. 1 


\begin{tabular}{|l|lr|l|}
\hline Short & be & passives & \\
15 & - & \\
Prepositional passives & passives & \\
Bare & passives & \\
- & passives & 16 \\
Have & passives & \\
1 & passives & \\
Get & passives & \\
- & & \\
Embedded & & $\mathbf{7 6}$ \\
\hline Concealed & & \\
\hline Adjectival & & & \\
- & & & \\
Grand Total & & & \\
\hline
\end{tabular}

The table above shows the total number of passive clauses in each of our data and the frequency of occurrence of the different types. As can be seen, passive clauses are highly significant in the speeches occurring 76 times in the data. The short be passive is the most significant with sixty-seven (67) occurrences, followed by the long be passive occurring five (5) times. Bare passive occur three (3) times while have passive occur only once (1). Thus, the short be passive is the most commonly used by politicians.

\section{Conclusion}

So far, this paper has examined the use of the passive clause in political speeches. The passive clause is an aspect of the English language that has not received popular attention as a tool of analysis of speeches. Even though fragments of the general functions of the passive clause can be gleaned in some grammar books, its deployment in political speeches has not been adequately explored. This paper has revealed that different kinds of passive clause (including one newly discovered by the authors) exist, but that it is only be passives that are commonly used. It is further revealed that the short be passive is preferred over the long be passive as evident in our data and analyses. The analysis has further revealed that passive clauses are used for the purpose of foregrounding information or achieving information focus which of course are for various reasons. This is why Sornig (1989:95) writes that:

... there is no such thing as a "pure", unbiased statement. The process of verbalizing thoughts and transmitting ideas involve the simultaneous signaling of purposes, aims and wishes along with the message itself. 
In other words, the passive clauses are used for achieving certain "purposes, aims and wishes" which can only be inferred by a careful reader/listener. This paper has succeeded in identifying six novel functions of the passive clause in a connected discourse. Further studies can examine the use of the passive clause in religious sermons.

\section{References}

Abuya, J. (2012). A pragma-stylistic analysis of President Goodluck Ebele Jonathan's inaugural speech. English Language Teaching, Vol. 5, No. 11, 8-15. https://doi.org/10.5539/elt.v5n11p8

Adetunji, A. (2009). Speech acts and rhetoric in the inaugural addresses of Nigeria's President Olusegun Obasanjo and America's President George W. Bush. In Odebunmi, A., Arua E., \& Arimi S. (Eds), Language, genre and politics. (A festschrift for Y.K. Yusuf) 275-296.

Akinkurolere, S.O. (2011). A political leader as a linguist: A speech acts analysis of President Barack Obama's victory and inaugural speech. UNAD STUDIES IN LANGUAGE AND LITERATURE Vol. 4.1 (1-12).

Akinwotu, S.A. (2015a). Vision for sustainable development: pragmatic strategies of media political competitive encounters. International Journal of Language and Literature, USA, Vol. 3, No. 2, pp. 134-143. https://doi.org/10.15640/ijll.v3n2a14

Akinwotu, S.A. (2015b). Pragmatic functions of language use in elections crises in Nigeria. In Madonna Journal of English and Literary Studies. Department of English, Madonna University, Okija. Nigeria. Vol. 2, No. 6, pp. 87- 99

Akinwotu, S.A. (2016). Rhetoric in selected speeches of Ọbafemi Awolọwọ and Moshood Abiọla. Ihafa: A Journal of African Studies, 8: 2 (36-58)

http://ihafa.unilag.edu.ng/article/viwe/607/306

Aschale, A. (2013). A critical discourse analysis of Barack Obama's speech vis-a-viz Middle East and North Africa. http://isearch.babylon.com/?q=a critical discourse analysis of barack obama's speeches vis-à-vis middle east and north Africa Ibabsrc tib ssmntrld \& 86775. retrieved 614/2015.

Ayeomoni, O. (2005). A linguistic-stylistic analysis of some political speeches of past Nigerian military rulers In Oyeleye, Lekan (Ed), Language and discourse in society Ibadan: Hope Publications. 199-213.

Ayoola, K. (2005). Interpreting Nigerian political discourse. A study of President Olusegun Obasanjo's July 26, 2005 address to Nigeria's National Assembly. Papers in English and Linguistics (PEL) vol. 6 1-13.

Bloor, T., \& Bloor, M. (1995). The functional analysis of English: A hallidayan approach. London: Longman. 


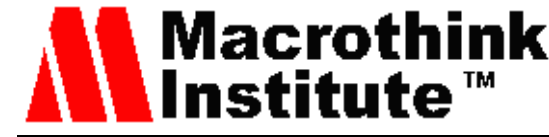

Fontaine, L. (2013). Introduction: Choice in contemporary systemic functional theory In Fontaine, L. Bartlett, T. and O'Grady .G (Eds), Systemic functional linguistics. United Kingdom: Cambridge University Press 1-12.

Halliday, M.A.K (1994). An introduction to functional grammar, 2nd Edition. London: Arnold.

Jabber, K.W., \& Jinquan, Z. (2013). The modal verbs: A speech act of request in the speech of the President of the United States Barak Obama. The Criterin. An International Journal in English. Issue 12. 1-13.

Jarraya, S. (2013). Persuasion in political discourse: Tunisian President Ben Ali's last speech as a case study. http://isearch.babylon.com/?qpersuasioninpoliticaldiscourse\%313tunisian president'slastspeechasacasestudy\&babsrc $=$ TBSS\&mntrld $=867758$.

Kirkpatrick, B. (2009). Correct English. Glasgow: Geddes and Gnesset.

Martin, J.R., \& Maltienssen, C.M. (1997). Working with systemic functional grammar. London: Arnold.

Nahrkhalaji, S.S (n.d). Language, ideology and power: A critical approach to political discourse research./aun.ac.ir/pd/shafiee-nahrkhalajiold/pdfs/ paperc_9003paf. Retrieved 25/3/2017.

Omotunde, S.A. (2014). A pragmatic analysis of independence anniversary speeches of Nigerian heads of government. Unpublished Ph.D thesis. Department of English and Literary Studies, Ekiti State University, Ado-Ekiti.

Okpanachi, M. (2009). Discourse analysis of President Obasanjo's national address on the Nigerian Labour Congress on 8th October, 2003 In Odebunmi, A. Arua, E. and Arimi, S. (Eds), Language, gender and politics. Lagos: Concept Publication.

Probst, R., Anderson, R. \& Brinnin, M.J. et al (1997). Elements of literature. New York: Harcourt Brace and Company.

$\mathrm{Pu}, \mathrm{C}$. (2007). Discourse analysis of President Bush's speech at Tsinghua University. China: Intercultural Communication Studies xvi: 205-216. https://doi.org/10.1.1.483.2023

Pullum, G.K (2014). Fear and Loathing of the English passive. http://www. sciencedirect.com/science/article/pii/so271530913000980. Retrieved 2/3/2017. https://doi.org/10.1016/j.langcom.2013.8.009

Ranney, A. (1975). The governing of men, Maison: Wiscousin.

Sornig, K. (1989). Some remarks on linguistic strategies of persuasion In Wodak, R. (Ed), Language, power and ideology. Amsterdam: John Benjamins.

Thorne, S. (2008). Advanced English language. New York: Macmillan

van Dijk, T.A (1997). What is political discourse analysis? Belgian Journal of Linguistics. Vol. 11. 11-52. 


\section{Macrothink}

Journal for the Study of English Linguistics

ISSN 2329-7034 2018, Vol. 6, No. 1

Wang, J. (2010). A critical discourse analysis of Barack Obama's speeches. Journal of Language Teaching and Research. Vol. 1, 3. 254-261. https://doi.org/10 4304/j1tr.1.3.254-261

\section{Copyright Disclaimer}

Copyright for this article is retained by the author(s), with first publication rights granted to the journal.

This is an open-access article distributed under the terms and conditions of the Creative Commons Attribution license (http://creativecommons.org/licenses/by/3.0/). 